\title{
Use of Gamification in the IB History Class and as a Tool for Form Teacher. New Empirical Research and Solutions
}

KEY WORDS

IB, gamification, form teacher, education, history

\begin{abstract}
Janiec Jerzy, Use of Gamification in the IB History Class and as a Tool for Form Teacher. New empirical Research and Solutions [Użycie gamifikacji na lekcjach historii IB oraz jako narzędzia dla wychowawcy. Nowe empiryczne badanie i rozwiązania]. Kultura - Społeczeństwo - Edukacja nr 1(7), 2015, Poznań 2015, pp. 105-120, Adam Mickiewicz University Press. ISBN 978-83-232-2944-5. ISSN 2300-0422

This article is a presentation of new empirical research and solutions for educators who tend to examine new methods and philosophies designed for improving teaching-learning process around the world. For that purpose, the author is introducing reader to the International Baccalaureate (IB) three-dimenstional way of creating school's curriculum with concept-based approach and idea to transfer knowledge between disciplines using global, key and related concepts. Accomplishment of this work provides a chance to form solutions according to each school's 'wants and needs', e.g. focusing on stimulation of pupils behaviour by implementing the Point System of Behavioral Assessment like in the IB World School No. 006654 case. And then teachers are able to standardize new teaching methods, such as gamification, successfully implementing them in their classes. What's more gamification can be easily used as a tool for form teachers in order to improve pupils' social skills and strengthening their involvement in a lesson.
\end{abstract}

\section{Introduction}

Author of this paper is a history and social studies teacher as well as form teacher in the IB World School No. 006654 International School of Bydgoszcz located in Kuyavian-Pomeranian Voivodeship (Telecki, 2015) and would like to summarize proprietary pedagogical as well as methodical achievements and accomplishments from the school year 2014/2015. 
The empirical research refers to use of gamification covering three different aspects and situations of teaching - learning process, specifically:

- preparations for Polish educational system examinations [Test Szóstoklasisty, ed. by JJ] with Grade 4, PYP's 10 years old teenagers, organized as extra curricular activities for students - 3 students in total;

- regular IB history and social studies classes with Grade 6, MYP's 12 years old teenagers, and Grade 7, MYP's 13 years old teenagers - 12 students in total;

- as a Grade 7 form teacher who thanks to observations, consultations with other schoolteachers, psychologist's opinions and students' questionnaires, including self- and peer-assessment, was able to emphasize the class's 'wants and needs' -7 students in total.

The main goal was to stimulate each class's engagement, academic performance and soft skills like collaboration, empathy in a lesson throughout real-life scenarios or historical times special setting including Role Play Game (RPG) basis in order to observe desirable behaviors. Due to the fact that the ISOB is quite young international community ${ }^{1}$ and there was a necessity to provide computers at school for each learner, besides students' technological devices, a representative number of them equals 15 . If it comes to differentiation based on gender we have 4 girls and 11 boys. The research time-frame under investigation was estimated for 4 months, from March to June 2015.

What's more the school in cooperation with democratic institutions, namely Students' Council and Parents' Council designed, implemented and used behavioral assessment system in October 2014. During each school year students are collecting 'plus points' for appropriate actions and 'minus points' for inappropriate actions. Generally, form teachers are required to prepare special reports for pupils analyzing and transferring their behavioral assessment points into adequate marks monthly (ISOB, 2014: 44-45).

This is the reason why the author of this paper decided to use free online educational RPG - "Classcraft" (Classcraft, 2015) - and set some principles which were presented to pupils in interactive way (Janiec, 2015).

\section{Key words, rules and abbreviations}

'International Baccalaureate' (IB) ${ }^{2}$ is an international educational fully flexible and globally well-known cycle which consists of four programmes, namely Pri-

\footnotetext{
${ }^{1}$ History and mission of the school, ibidem: "The Non-Public General Educational Complex of the University of Kazimierz Wielki was formed on the 2nd of March 2009 (...)".

${ }^{2}$ International Baccalaureate Organization, IBO, www.ibo.org (dostęp: 16.07.2015).
} 
mary Years Programme (PYP) (IB, 2009) - Polish Primary School equivalent, Middle Years Programme (MYP) (IB, 2014) - Polish Gymnasium equivalent, Diploma Programme (DP) (IB, 2009) - Polish High School equivalent, and IB Career - related Certificate (IBCC) (IB, 2012), founded for students in the age from 3 to 19 in Geneva (Switzerland) in 1968 (Janiec, 2014: 185-186). According to nowadays statistics the IB philosphy has been already implemented in 146 countries including Poland ${ }^{3}$. So in essence, more than 1 million teenagers is aquainted with this project.

One of the main aims of it, from practical point of view, is to design, implement, applicate and evaluate concept-based curriculum and instructions (Erickson, 2012: 3). Lynn H. Eriksson clearly states that we are dealing with a threedimenstional model of teaching and learning where on the one hand we have to define what students should know (factual content) and on the other hand what kind of skills learners should be equipped with, adding to this disciplinary concepts, generalizations and principles (Erickson, 2012: 3). Undoubtedly, the IB educational option stands in opposition to the traditional model of arranged thematically two-dimensional curriculum focusing solely on knowledge and skills, not necessarily on interdisciplinary transfer of knowledge. Moreover, the already mentioned flexibleness means that educators are able to readjust its requirements on specific countries educational system obligations towards teachers and curricular contents, which must be covered.

The transfer of knowledge is achieved thanks to six global contexts occurring in each subject: Identities and Relationships (Who am I? Who are we?), Orientation in Time and Space (What is the meaning of 'when' and 'where'?), Personal and Cultural Expression (What is the nature and purpose of creating expression?), Scientific and Technical Innovation (How do we understand the World in which we live in?), Globalization and Sustainability (How is everything connected?) and Fairness and Development (What are the consequences of our common humanity?) (IB, 2014: 18-19). They prove how learning best take place in context, e.g. covering in history and social studies classes Identities and Relationships inquiry students will explore: identity; beliefs and values; personal, physical, mental, social and spiritual health; human relationships including families, friends, communities and cultures; what it means to be human. It automatically corresponds with possible explorations to develop, e.g. competition and coopera-

\footnotetext{
${ }^{3}$ We have to take into account 44 schools in total, source: International Baccalaureate Organization, IBO, http://www.ibo.org/en/programmes/find-an-ib-school/?SearchFields.Region=ibaem\&SearchFields. Country $=$ PL $\&$ SearchFields.Keywords $=\&$ SearchFields.Language $=\&$ SearchFields. BoardingFacilities $=\&$ Sea rchFields.SchoolGender=\&page=3, 16.07.2015.
} 
tion, identity formation, etc. Next step is to choose one key concept ${ }^{4}$ and related concepts ${ }^{5}$ from open IB catalogue. Our choices should correspond with the global contexts and they can be used as general topics in our unit as well.

History is one of the main representatives of a subject group entitled 'Individuals and Societies' in IB. To visualize how this philosophy works we are going to favor 'Ancient Egypt' unit with Identities and Relationships global context. Next step is to decide that our key concept will be, for instance 'Culture' and related concept 'Significance'. Knowing characteristics of Ancient Egyptian art we can initiate a problem-solving topic: Why did rulers portray themselves as descendants and agents of the gods? Teachers adopt suitable materials, methods and technics of teaching.

The simplest way to define a term 'Gamification' is to understand it as a phenomenon transpiring when we "use (...) game design elements in non-game contexts" (Detering, Dixon, Khaled, Nacke, 2011; Werbach, Hunter, 2012: 17-34, 69-84, 85-103), e.g. in education, "to solve problems [from teachers' point of view: students' motivation, misbehaviors, lack of productivity working in groups, issues with organizational, self-management, time-management skills, etc., on the other hand designing a problem-solving topics, ed. by JJ] and engage users [students but at certain point also teachers, ed. by JJ]" (Zichermann, 2015). According to our latest research it is more likely for this idea to be introduced when school designs a gamification-friendly environment like the ISOB's taking into action the Point System of Behavioral Assessment ${ }^{7}$, first. The biggest advantage of it is a fact that each learner is aware of positive and negative consequences, which are determined by a specific response to the given situation.

General provisions are presented in the ISOB Handbook. The most important are as follows: "The behavior mark should take into consideration the pupil's overall functioning in the school environment with respect to all the members of the school community and to school facilities. Form teacher's duty is to acquaint his students and their parents with detailed grading criteria of a student's behavior at the first teacher-parent meeting. The form teacher establishes a behavior mark basing on aggregated pupil's points, teachers' opinions and student's self-assessment. The mark is final. Behavior grade does not influence par-

${ }^{4}$ Ibidem, p. 15: "Key concepts, contributed from each subject group, provide interdisciplinary breadth to the programme. Key concepts are broad, organizing, powerful ideas that have relevance within and across subjects and disciplines, providing connections that can transfer across time and culture."

${ }^{5}$ Ibidem, loc. cit.: "Related concepts, grounded in specific disciplines, explore key concepts in greater detail, providing depth to the programme. They emerge from reflection on the nature of specific subjects and disciplines, providing a focus for inquiry into subject-specific content."

${ }^{67}$ Ibidem, p. 106.

${ }^{7\urcorner}$ ISOB, loc. cit. 
ticular subject grades." The Gamification part starts at the beginning of each semester when students are given a credit of 400 points which is equal to Polish equivalent of Good behavior grade. "The student's self-assessment is graded in the following way: Excellent +15 points, Very good +10 points, Good +5 points, Satisfactory 0 points, Non-satisfactory -5 points, Reprehensible -10 points" . If any learner obtained 100 negative points cannot get Excellent behavior grade, if anyone got reprimanded by a form teacher can obtain only up to Good behavior grade, but if anyone got reprimanded by the school principal can obtain only up to Satisfactory behavioral grade ${ }^{10}$.

The behavior grading system (the numbers represent collected points) ${ }^{11}$ :

- 590 and more = Excellent (student is handed in a Polish Certificate with a distinction - average from all of the school subjects needs to equal or be above 4.75)

- 520-589 = Very good (student is handed in a Polish Certificate with a distinction - average from all of the school subjects needs to equal or be above 4.75)

- 400-519 = Good (student is not handed in a Polish Certificate with a distinction even if average from all of the subjects equals or is above 4.75)

-280-399 = Satisfactory

-210-279 = Non-satisfactory

- 209 and less = Reprehensible

Table 1. Positive points. Source: ISOB Handbook 2014

\begin{tabular}{|c|l|c|}
\hline No. & \multicolumn{1}{|c|}{ Criteria } & Points \\
\hline 1. & $\begin{array}{l}\text { Participation in competitions, sporting and artistic events (understood } \\
\text { as a form of school representation) }\end{array}$ & 30 \\
\hline 2. & $\begin{array}{l}\text { Diligent adherence to the rules on a school dress (assessed once a } \\
\text { month) }\end{array}$ & 20 \\
\hline 3. & Praise put into the class register & 30 \\
\hline 4. & $\begin{array}{l}\text { Active participation in a lesson, demonstration of the IB Learner Profile } \\
\text { Attributes }\end{array}$ & 30 \\
\hline 5. & $\begin{array}{l}\text { Contribution to the school and class (organization or help with school } \\
\text { events, decorations, etc.), other than CAS }\end{array}$ & $40-$ once per \\
\hline 6. & Impeccable manners (points are granted by a form teacher) \\
\hline
\end{tabular}

\footnotetext{
${ }^{8}$ Ibidem.

${ }^{9}$ Ibidem.

${ }^{10}$ Ibidem.

${ }^{11}$ Ibidem.

${ }^{12}$ Description and sources: Janiec, 2014: 198 and footnote 29.
} 


\begin{tabular}{|c|l|c|}
\hline No. & \multicolumn{1}{|c|}{ Criteria } & \multicolumn{1}{|c|}{ Points } \\
\hline 7. & $\begin{array}{l}\text { Exemplary attendance (lack of unexcused hours, lack of remarks on } \\
\text { being late) }\end{array}$ & $\begin{array}{c}20-\text { once per } \\
\text { term }\end{array}$ \\
\hline 8. & $\begin{array}{l}\text { Conscientious fulfillment of obligations (effective execution of a func- } \\
\text { tion in the class/school council, duties, etc.) }\end{array}$ & $\begin{array}{c}30-\text { once per } \\
\text { term }\end{array}$ \\
\hline
\end{tabular}

Table 2. Negative points. Source: ISOB Handbook 2014

\begin{tabular}{|c|l|c|}
\hline No. & \multicolumn{1}{|c|}{ Criteria } & Points \\
\hline 1. & Truancy. & 50 \\
\hline 2. & Unexcused absence (each hour). & 5 \\
\hline 3. & $\begin{array}{l}\text { Being late for a lesson (each lesson) - 1 point per minute/ up to 5 points } \\
\text { max. }\end{array}$ & max. 5 \\
\hline 4. & $\begin{array}{l}\text { Student dress and appearance: distracting, provocative, eccentric outfit / } \\
\text { offensive slogans or symbols. Points will be given once every month. }\end{array}$ & 10 \\
\hline 5. & Abusive language, gestures and comments. & 10 \\
\hline 6. & Leaving the school premises during the lessons and breaks. & 20 \\
\hline 7. & Admonition or reprimand notes written in the class's register. & 25 \\
\hline 8. & $\begin{array}{l}\text { Technology misuse-inappropriate use of electronic devices (the cell } \\
\text { phones, audio devices, cameras and voice recorders, etc.) during the } \\
\text { lessons and breaks without teacher permission. }\end{array}$ & 30 \\
\hline 9. & $\begin{array}{l}\text { Using mobiles or social network websites and other available internet } \\
\text { features to abuse, threaten and harass school staff members, teachers } \\
\text { and students. }\end{array}$ & 70 \\
\hline 10. & $\begin{array}{l}\text { Not being prepared for the class (e.g. no homework or necessary student } \\
\text { equipment). }\end{array}$ & 10 \\
\hline 11. & Acts of physical aggression (active participation in a fight). & 100 \\
\hline 12. & Passive participation in a fight. & 30 \\
\hline 13. & Vandalism. & 100 \\
\hline 14. & Littering. & 10 \\
\hline 15. & $\begin{array}{l}\text { Possession and uses of any dangerous objects (forbidden by law, posing } \\
\text { hazard to people's health and life) }\end{array}$ & 100 \\
\hline 16. & $\begin{array}{l}\text { Smoking, drinking alcohol, drugs or substance abuse within the school } \\
\text { premises }\end{array}$ & 100 \\
\hline 17. & Theft. & Cheating, plagiarism and forgery. \\
\hline 19. & Non - fulfillment of any teacher's or school worker's requests or orders. \\
\hline
\end{tabular}

After in-depth analysis of changes at the ISOB connected with adaptation of new behavioral assessment system and evaluation of 'wants and needs' as a history, social studies teacher and form teacher it was more than indisputable to search for constructive and inspirational tool. Guidance was found in the 
"Classcraft" a free online fantasy-themed educational RPG. Learners choose a class from warrior, healer or mage and form one team or small teams. By using many conventions traditionally found in games today, students could level up, and earn powers that have real-world consequences in order to use their characteristic individual skills in a collaborative work. Acting as a gamification layer around any existing curriculum, the game transforms the way a class is experienced throughout the school year in a long-term effect approach. Students can also lose hit points for negative behaviors unless another player intervenes and handles a power on their favor if a Gamemaster does not block this ability. If a student loses all of his/her hit points, he/she "falls in the battle" and must face the repercussions (e.g. writing an extra essay, pop quiz or make a presentation with a references). In each RPG game we come across abbreviations as follows: HP (Health Points) stands for Behavioral Assessment Points; AP stands for manna points thanks to which we can use our skills; XP stands for Experience Points, they are summed up with HP, but after collecting adequate number of those our character is able to level up and next step is to choose and learn new skill.

As with special skills, there are some predetermined suggestions, but these can be customized. In PYP and MYP history classes most of abilities were similar:

Table 3. Warrior's skills. Source: http://jerzyjaniec.wix.com/great7middleages\#!game-info/c9qb ${ }^{13}$

\begin{tabular}{|l|l|c|}
\hline \multicolumn{1}{|c|}{ Skills } & \multicolumn{1}{|c|}{ Descriptions } & $\begin{array}{c}\text { Costs in } \\
\text { APs }\end{array}$ \\
\hline Protect 1 & $\begin{array}{l}\text { The warrior can take up to 10 damage instead of his/her teammate, } \\
\text { receiving only 80\% of the initial damage. }\end{array}$ & 10 \\
\hline First Aid & The warrior gains 1 AP/level for a minimum of 5 AP. & 10 \\
\hline Hunting & The warrior can finish eating after the bell in class. & 5 \\
\hline Protect 2 & $\begin{array}{l}\text { The warrior can take up to 20 damage instead of his/her teammate, } \\
\text { receiving only 65\% of the initial damage. }\end{array}$ & 15 \\
\hline Ambush & The warrior can hand in an assignment one day later ${ }^{14}$. \\
\hline $\begin{array}{l}\text { Counter } \\
\text { Attack }\end{array}$ & The warrior gets one hint on an exam question. & 20 \\
\hline Protect 3 & $\begin{array}{l}\text { The warrior can take up to 30 damage instead of his/her teammate, } \\
\text { receiving only 50\% of the initial damage. }\end{array}$ & 20 \\
\hline $\begin{array}{l}\text { Frontal } \\
\text { Attack }\end{array}$ & All team members can hand in an assignment one day later. & 30 \\
\hline $\begin{array}{l}\text { Secret } \\
\text { Weapon }\end{array}$ & $\begin{array}{l}\text { All team members can decide on the final assessment task for the } \\
\text { given unit. }\end{array}$ & 30 \\
\hline
\end{tabular}

${ }^{13}$ One of very important rules in "Classcraft" is that game principles can be changed by the Gamemaster during a contest.

${ }^{14}$ It stands not in opposition with the school rules - a student has additionally two days to bring assignment after the deadline, check the ISOB Handbook. 
Table 4. Healer's skills. Source: http://jerzyjaniec.wix.com/great7middleages\#!game-info/c9qb

\begin{tabular}{|l|l|c|}
\hline \multicolumn{1}{|c|}{ Skills } & \multicolumn{1}{|c|}{ Descriptions } & $\begin{array}{c}\text { Costs in } \\
\text { APs }\end{array}$ \\
\hline Heal 1 & A teammate gains 10 AP monthly. & 15 \\
\hline Sainthood & The healer can open or close a window. & 5 \\
\hline $\begin{array}{l}\text { Ardent } \\
\text { Faith }\end{array}$ & $\begin{array}{l}\text { During an exam the healer can ask the Gamemaster if his/her answer } \\
\text { to a question is correct (only once). }\end{array}$ & 10 \\
\hline Heal 2 & A teammate gains 20 AP monthly. & 20 \\
\hline $\begin{array}{l}\text { Favor of } \\
\text { Gods }\end{array}$ & The healer can listen to his/her iPod during classwork. & 20 \\
\hline Revive & $\begin{array}{l}\text { When a teammate (not including the healer) falls to 0 HP he/she } \\
\text { avoids all penalties and comes back to life with 1 HP. }\end{array}$ & 25 \\
\hline Heal 3 & A teammate gains 30 AP. & 20 \\
\hline $\begin{array}{l}\text { Healing } \\
\text { Circle }\end{array}$ & All team members, other than healer, gain 15 AP. & 30 \\
\hline Prayer & $\begin{array}{l}\text { All team members can decide on place and time of their trip (once a } \\
\text { month). }\end{array}$ & 50 \\
\hline
\end{tabular}

Table 5. Mage's skills. Source: http://jerzyjaniec.wix.com/great7middleages\#!game-info/c9qb

\begin{tabular}{|l|l|c|}
\hline \multicolumn{1}{|c|}{ Skills } & \multicolumn{1}{|c|}{ Descriptions } & $\begin{array}{c}\text { Costs in } \\
\text { APs }\end{array}$ \\
\hline $\begin{array}{l}\text { Manna } \\
\text { transfer }\end{array}$ & All team members except mages gain 7 AP points. & 35 \\
\hline Teleport & The mage can trade places with any other classmate & 5 \\
\hline Invisibility & The mage can leave the classroom to take something from the locker. & 10 \\
\hline $\begin{array}{l}\text { Manna } \\
\text { Shield }\end{array}$ & $\begin{array}{l}\text { The mage can transfer damage to his/her AP, at the cost of 3 AP per } \\
\text { HP prevented. }\end{array}$ & 0 \\
\hline $\begin{array}{l}\text { Cheat } \\
\text { Death }\end{array}$ & $\begin{array}{l}\text { A fallen teammate (other than the mage) can reroll the cursed die but } \\
\text { must accept the new outcome }\end{array}$ & 15 \\
\hline $\begin{array}{l}\text { Time } \\
\text { Warp }\end{array}$ & The mage gains extra 8 min. to beat an exam. & 35 \\
\hline $\begin{array}{l}\text { Fountain } \\
\text { of Manna }\end{array}$ & A teammate who is not a mage, replenishes all of his/her AP. \\
\hline $\begin{array}{l}\text { Clairvoy- } \\
\text { ance }\end{array}$ & All of the team members get one hint on an exam. & 40 \\
\hline $\begin{array}{l}\text { Mage } \\
\text { Circle }\end{array}$ & All team members gain an extra 5 min. to beat an exam. & 40 \\
\hline
\end{tabular}

The whole idea of gamification in the IB history and social studies classes was presented to the ISOB principal on February 2, 2015 (Janiec, 2015a). She was handed in lesson scenarios with game rules and a website adress. Thanks to her 
support and more importantly acquiescence Grade 7 students were introduced to the project on February 6, $2015^{15}$ first. All of them agree to join the Medieval story: "You wake up on a beach during a breathtaking sunset. The sun is about to disappear sailing into the red gulf on the Celestial Sphere. What a natural masterpiece!!! The most intriguing thing about this place is a Medieval Sandcastle, which stands very close to the sea. You don't know who you are, where you are, what are you doing on a sand beach. It seems to be the most difficult day in your life, but six other people repeat all of the already mentioned questions. No, it's not a coincidence. All of you had formed one of the greatest team in the Universe. Indeed, someone sees in you a threat. Now it is a time for investigation who? The only person who can help you in finding your identity, strengths and weaknesses as well as ability to group work is a... Historian"16.

\section{Gamification in the PYP}

According to Polish law there is a requirement to organize Polish, geography and history classes for Polish speakers in order to prepare them for aforementioned examinations resulting from educational system specifications. This is farreaching point for international community like the ISOB. But in the same time educators' assignment is to store a motivation in students in order to secure as many points as they are competent to writing tests.

On the grounds that gamification is enforced each test may be a one-day mission and each question a possibility to collect XP or necessary gold to exchange it with trained pets, assortments of new clothing or armor for our character in history lesson. Of course students can come across a giant cartoon monster and to deal with it they need to give a corrent answer on the question if not they lose HP. As far as we are concerned there is no adequate words to assess involvement or engagement of students in 45 minutes lesson noticing a breakthrough.

Grade 4 did amazing progress memorizing historical facts, figures and dates. They were working with historical sources in a written form and maps, pictures, photos, paintings, etc. How to interpret their words that 'we do not want to finish this lesson', as a misbehavior or a complement?

\footnotetext{
${ }^{15}$ Ibidem.

${ }^{16}$ Ibidem. Historian is a Gamemaster, so the teacher.
} 


\section{Gamification in the MYP - Grade 6 example}

Teaching history in the $21^{\text {st }}$ century, which might be called the Age of Technology, is quite ambitious and very inspiring encounter especially when Grade 6 was covering the last school year unit: 'Ancient China' with global context: Scientific and Technical Revolution. 'Perspective' was chosen as the key concept and 'Innovation and Revolution' as related concept. Taking into account ancient Egyptians, Mesopotamians, Greeks and Romans achievements the question was how we can define the 'Chinese Perspective'?

Here is a place for successful gamification use and summative assessment in a form of project (task) for students ${ }^{17}$. The plan was to make a documentary on ancient civilizations. Firstly, they were aware to share roles in group: a leader, a secretary, a research investigator who stays in contact with the teacher, a timekeeper and a specialist who presents the class's work. Secondly, the requirement was to create a free licensed account on 'WeVideo - Free Online Video Editor' to create 60 seconds trailer and get extra $500 \mathrm{XP}$ (the whole class). Next step was to answer several questions: where is this documentary going to be shown (or where do you envision it being shown)? Who is your targeted/primary audience? Answering these questions helps learners determine the content, tone, style and length of their documentary. Then they started building their audience: launching a Facebook page (or other social media) immediately and building a website with a blog that they updated (this built "organic" web traffic) - another plus 750 XP. Content must include ancient Greece, Rome and China similarities and differences if it comes to gods and creation myths, political systems and inventions (including references plus $1000 \mathrm{XP}$ for the whole class). A time-frame for project was 3 weeks ( 2 lessons periods weekly).

During this time period girls and boys followed their character's life being logged in on "Classcraft" accounts. They were taking care of XP and gold points thanks to which they could buy clothes, armor and train pets. But in the same they were looking forward to be awarded by the IB Learner Profile Attributes as well. What was the biggest surprise a female student who generally was the shyest in the class became a leader. She swopped roles with a male learner who in 9 out of 10 activities used to be a man in charge. Moreover, he spotlighted her strengths - organizational skills, reflective nature and being knowledgeable. The final products are just outstanding ${ }^{18}$.

${ }^{17}$ More information on IB assessed criteria: idem, Możliwości wykorzystania..., p. 185 and footnote no. 11 .

${ }^{18}$ Grade 6, The Civilization Fight, http://grade6isob.wix.com/thecivilizationfight (dostęp: 20.07.2015). 


\section{Form teacher and Grade 7 case}

"Classcraft" in Grade 7 history and social studies classes was used during two units "Medieval Europe: Society" (March-April) and "Medieval Europe: Spirituality" (May-June). It was the best class from 2013/2014 school year with seven tremendous individualists. The main aim for the form teacher and subject teacher in this situation was to create, implement and develop a new classroom environment thanks to which pupils would be more welcome to use their individual skills in a collaborative work. Dear readers please find a list of activities and feedback below:

Table 6. New classroom environmental students' activities and teacher's feedback. Source: http://jerzyjaniec.wix.com/great7middleages\#!game-info/c9qb

\begin{tabular}{|c|c|}
\hline Activities & Feedback \\
\hline Effective negotiations & $\begin{array}{l}\text { Students are given ability to negotiate. They } \\
\text { can use it once per two month time to negoti- } \\
\text { ate the final project grade. The Historian } \\
\text { makes his decision independently when the } \\
\text { group is ready to be awarded. }\end{array}$ \\
\hline $\begin{array}{l}\text { Active listening - students are listening to } \\
\text { each other even if their opinions differ }\end{array}$ & $\begin{array}{l}\text { Students are given Ability to listen badge. The } \\
\text { whole class is advised on helpful changes in } \\
\text { order to get better mark making a project. The } \\
\text { Historian makes his decision independently } \\
\text { when the group is ready to be awarded. }\end{array}$ \\
\hline $\begin{array}{l}\text { Roles in group work - students share their } \\
\text { roles }\end{array}$ & $\begin{array}{l}\text { - A Leader (with a crown): makes sure that } \\
\text { every voice is heard and focuses work around } \\
\text { the learning task. } \\
\text { - A Secretary (with a pen): compiles group } \\
\text { members' ideas on collaborative graphic or- } \\
\text { ganizer and writes on the board for the whole } \\
\text { class. } \\
\text { - A Time-keeper (with a watch): encourages the } \\
\text { group to stay on a task. } \\
\text { - A Research-Investigator (with a question } \\
\text { mark): is responsible for a contact with the } \\
\text { Historian and if there will be any problem } \\
\text { with a task he/she requests help. } \\
\text { - A Specialist (with a sunglasses): presents the } \\
\text { group's finished work. } \\
\text { - An Errand Monitor (with Hermes schoes): } \\
\text { briefly leaves the group to get supplies. } \\
\text { - An Innovator (with a flying machine): en- }\end{array}$ \\
\hline
\end{tabular}




\begin{tabular}{|c|c|}
\hline Activities & Feedback \\
\hline & $\begin{array}{l}\text { courages imagination and contributes new } \\
\text { and alternative perspectives and ideas. } \\
\text { Each role in a group equals additional skill and } \\
\text { attribute. Thanks to them students are able to } \\
\text { restore AP points monthly. }\end{array}$ \\
\hline Rights and Responsibilities in a group work & $\begin{array}{l}\text { Each student receives } 10 \text { diamonds once after } \\
\text { distribution of duties. Student who fulfills all } \\
\text { of the duties receives one diamond weekly. } \\
\text { Student who does not fulfill all of the given } \\
\text { duties will not receive a diamond and his/her } \\
\text { skills are blocked for one day. }\end{array}$ \\
\hline Diplomacy & $\begin{array}{l}\text { The whole class receives } 5 \mathrm{XP} \text { points thanks to } \\
\text { usage of a proper language. }\end{array}$ \\
\hline Ability to recognize emotions & $\begin{array}{l}\text { Students need at least five weeks to gain this } \\
\text { ability collecting } 1 \text { point as the whole class per } \\
\text { week. A difficulty is to recognize emotions and } \\
\text { responds adequately to the emotional states. } \\
\text { This is called empathy. Thanks to this ability } \\
\text { the whole group's experience is leveled up by } \\
10 \text { points in each week if the members are } \\
\text { going to solve any problem working together. }\end{array}$ \\
\hline IB Learner Profile Attributes & $\begin{array}{l}\text { In each lesson students can be given individu- } \\
\text { ally } 5 \mathrm{HP} \text { and XP by representing one of } 10 \mathrm{IB} \\
\text { Learner Profile Attributes namely being In- } \\
\text { quirer, Knowledgeable, Thinker, Communica- } \\
\text { tor, Principled, Open-minded, Caring, Risk- } \\
\text { taker, Balanced, Reflective. Collecting } 10 \text { out of } \\
10 \text { of them opens a way to exchange them with } \\
\text { AP. }\end{array}$ \\
\hline Impeccable manners & $\begin{array}{l}\text { A chance to be given } 40 \mathrm{HP} \text { and XP. Student } \\
\text { is also given a White Armor Badge - a symbol } \\
\text { of imeccable manners. It can disappear com- } \\
\text { pletely because learner collect too much nega- } \\
\text { tive points and it affects manna power points. } \\
\text { Student would not be able to use the most } \\
\text { powerful skill on the } 9^{\text {th }} \text { level for one month. }\end{array}$ \\
\hline Involvement in the school events & $\begin{array}{l}\text { Students are given } 30 \mathrm{HP} \text { and } \mathrm{XP} \text { as well as } 10 \\
\text { diamonds for organizing a school event; } 5 \\
\text { diamonds for active participation; coordinator } \\
\text { of the event is given Organizational Ability } \\
\text { Prize ( } 50 \text { diamonds), if the whole class will } \\
\text { actively participate in the event the coordina- } \\
\text { tor would choose a task different than quiz. }\end{array}$ \\
\hline
\end{tabular}




\begin{tabular}{|l|l|}
\hline \multicolumn{1}{|c|}{ Activities } & \multicolumn{1}{c|}{ Feedback } \\
\hline Fulfilling duties & $\begin{array}{l}\text { Students are given } 30 \mathrm{HP} \text { and XP as well as } \\
1 \text { diamond for fulfilling duties each day. Hav- } \\
\text { ing two students required to do the work, both } \\
\text { is required to share their work. }\end{array}$ \\
\hline \multirow{2}{*}{$\begin{array}{l}\text { Attendance and none remarks on being late } \\
\text { in the register }\end{array}$} & $\begin{array}{l}\text { Students are given 20 XP monthly and 20 HP } \\
\text { once per term. Thanks to this statistics the } \\
\text { learner is given additionally 50 XP and has } \\
\text { a chance to restore somebody's AP from the } \\
\text { class. }\end{array}$ \\
\hline Praise in the register & $\begin{array}{l}\text { Students are given } 30 \text { HP and XP as well as } \\
1 \text { diamond per 1 praise. }\end{array}$ \\
\hline \multirow{2}{*}{ Exchanging diamonds } & $\begin{array}{l}20 \text { diamonds = } 5 \text { XP } \\
50 \text { diamonds = } 10 \text { XP } \\
100 \text { diamonds = 25 XP }\end{array}$ \\
\hline Level up & $\begin{array}{l}\text { To level up a character students need to collect } \\
40 \text { XP in the beginning of our game. }\end{array}$ \\
\hline
\end{tabular}

Students sticked to the rules and performed better than in the first term. The whole class average in the end of the school year 2014/2015 equals 5,4 (first term: 4,98 ) and was the best at school with the highest average 5,93 and lowest 4,87 from all of the subjects. There was only one unjustified hour and three marks on being late in the class register. All of the duties were fulfilled and all of the badges and attributes collected. What's more students actively participated in all school events and they organized three trips (two of them in Poland took place this school year, the third one abroad to England was postponed). Grade 7 has become a team, with one praise in the register as the whole class, who shares role in a group work. The biggest encounter they have stumbled upon was to recognize emotions their classmates. Students agreed that most common one for everybody is being stressed before exams, tests and quizzes from majority of subjects. There was a need to organize a lesson about dealing with stress during meeting with a form teacher one hour weekly.

With a reference to the units, learners were obliged to write and perform a play entitled: "Medieval Times in the Eyes of G7" as two seperate groups. But they assisted each other in making videos and sharing propositions to design a website. The final products are magnificent (Janiec, 2015b).

\section{Conclusions and recommendations}

- Behind each solution and idea stands at least individual - inventor and group of people who support him. 
- The teacher's personality traits and skills including eagerness for improved change make a difference.

- One of principles in education should be not to underestimate a new educational course which was chosen by educators at the given school to be implemented, for instance the IB philosophy.

- There should be always a brainstorm of ideas and finally consensus among three crucial groups of interest: students, parents, the governing body, and educators on a new educational form of environment like in the behavioral assessment case.

- In the interest of each school should be creation of interdisciplinary curriculum in order to provide a space for transfering knowledge between subjects proving existance of connection among different academic disciplines for students.

- Gamification and its tools are satisfactory method as well as apparatus to measure students' involvement and engagement in a lesson on lower level of education.

- Gamification and its tools might be favorable apparatus for form teachers and subject teachers to stimulate students behavior in order to achieve their goals after in-depth research connected with defining learners 'wants and needs'.

- This research paper should be interpreted as a prologue for future analyzis.

\section{Literatura}

Detering S., Dixon D., Khaled R., Nacke L. (2011). From Game Design Elements to Gamefulness: Defining Gamification. "MindTrek'11, September 28-30.

Erickson L.H. (2012). Concept-based Teaching and Learning. IBO.

IB (2009). Diploma Programme. From Principles into Practice. Cardiff Gate.

IB (2009). The Primary Years Programme. A basis for practice. Cardiff Gate.

IB (2012). IBCC: the $4^{\text {th }} I B$ Programme. IBO.

IB (2014). MYP from Principles into Practice. For use from September 2014/January 2015. Cardiff Gate.

ISOB (2014). Middle Years Programme. Handbook for parents and students 2014/2015. Bydgoszcz. Janiec J. (2014), Możliwości wykorzystania interdyscyplinarnego odtwórstwa historycznego na poziomie szkoły podstawowej i gimnazjum oraz liceum w programie IB (International Baccalaureate). [W:] A. Kosecki (ed.). Młodość historii. T. II. Materialne i niematerialne aspekty rekonstrukcji historycznej, Toruń, s. 183-192.

Werbach K., Hunter D. (2012). For the Win: How Game Thinking Can Revolutionize Your Business, Philadelphia. 


\section{Źródła internetowe:}

Classcraft Team, Classcraft, www.classcraft.com (dostęp: 19.07.2015).

Grade 6, The Civilization Fight, http://grade6isob.wix.com/thecivilizationfight (dostęp: 20.07.2015).

Janiec J., (2015a). Great 7 in the Middle Ages, www.jerzyjaniec.wix.com/great7middleages (dostęp: 19.07.2015).

Janiec J., (2015b). Medieval Times in the Eyes of G7, http://jerzyjaniec.wix.com/g7atplay (dostęp: 21.07.2015)

International Baccalaureate Organization = IBO, IBO, http://www.ibo.org (dostęp: 16.07.2015).

Telecki M., (2015). Non-public General Education School Complex of Kazimierz Wielki University in Bydgoszcz International School of Bydgoszcz, www.isob.edu.pl (dostęp: 16.07.2015).

Zichermann G., A Long Engagement and a Shotgun Wedding: Why Engagement is the Power Metric of the Decade. Presentation, Gamification Summit, San Francisco, CA, 2011, http://goo.gl/ jlaO0 (dostęp: 20.08.2015).

\section{Użycie gamifikacji na lekcjach historii IB oraz jako narzędzia dla wychowawcy. Nowe empiryczne badanie i rozwiazania}

\section{Streszczenie}

Celem niniejszego artykułu jest zbadanie wpływu gamifikacji jako metody nauczania historii i wiedzy o społeczeństwie oraz jako narzędzia dla wychowawcy w szkole IB, na motywację i zaangażowanie oraz pracę w grupie uczniów w wieku od 10 do 13-14 lat. Autor przybliża organizację placówki międzynarodowej, w której sam pełni funkcję nauczyciela ww. przedmiotów. W celu analizy postawionego problemu badawczego wybrał on trzy klasy, w których naucza: odpowiednik polskiej klasy czwartej i szóstej szkoły podstawowej oraz pierwszej klasy gimnazjum. Przedstawił środowisko edukacyjne, w którym gamifikacja została wprowadzona, oraz zasady, na jakich opierała się rozgrywka między marcem a czerwcem roku szkolnego 2014/2015.

W pierwszej części pracy autor przedstawia i wyjaśnia potrzebne słowa kluczowe, zasady oraz skróty stosowane w pracy. Wychodzi od filozofii IB, jej struktury i organizacji oraz idei przewodniej w konstruowaniu trójwymiarowego programu nauczania, polegającego na transferze wiedzy na różnych przedmiotach szkolnych. Następnie opisuje środowisko edukacyjne i sposób narodzin gramifikacji, wyjaśniając jej definicję. Płynnie przechodzi do zasad gry i skrótów językowych.

W drugiej części pracy autor wychodzi od ustawowego zobligowania szkół publicznych i prywatnych do organizacji zajęć z języka polskiego, geografii i właśnie historii dla polskiego słuchacza. Sam prowadził zajęcia przygotowawcze do testu szóstoklasisty z klasą czwartą szkoły podstawowej. Stwierdza, że najważniejsza jest na nich odpowiednia motywacja i zaangażowanie uczniów, które można stymulować za pomocą gamifikacji. Autor utwierdza czytelnika w przekonaniu, że zupełnie inaczej podchodzi się do rozwiązywania testów, jeżeli całość przedstawi się jako jednodniową misję, a za każde dobrze rozwiązane zadanie można uzyskać nagrodę. Wspomniana nagroda może zostać wykorzystana do zakupu ubioru lub broni dla postaci z „Classcrafta” (specjalistycznego 
programu online do tworzenia postaci i zasad RPG na potrzeby edukacji) - maga, wojownika bądź kapłana.

Część trzecia: gamifikacja w MYP-ie na przykładzie klasy szóstej i czwarta: kwestia wychowawcy i jego klasy pierwszej gimnazjum stanowią podsumowanie osiągnięć uczniów ze starszych klas. Z jednej strony autor niniejszego artykułu przedstawia czytelnikowi możliwe scenariusze lekcyjne do wprowadzenia w ramach gamifikacji. Stwierdza on z całą pewnością, że dzięki nim uczniowie wykonali wspaniałą pracę. Prezentuje on również prace swoich uczniów, które można obejrzeć na stronach internetowych. Ponadto jako wychowawca autor dzieli się z rozwiązaniami przyjętymi w klasie, które się sprawdziły.

W konkluzjach i rekomendacji uznaje gamifikację i jej narzędzia za miernik zaangażowania uczniów wkładanego podczas zajęć dzięki wykorzystywanym do tego, wspomnianym w pracy, parametrom. Gamifikacja ma stanowić narzędzie dla stymulowania odpowiednich zachowań uczniów przez wychowawcę. Autor wierzy w to, że sprawdzalność tej metody nauczania wiąże się z odpowiednim środowiskiem edukacyjnym, w tym ze współpracownikami, odpowiednią filozofią nauczania i ze spełnianiem się jako nauczyciel. 